\title{
GRANULOCYTE-SPECIFIC ANTINUCLEAR FACTORS IN SERUM AND SYNOVIAL FLUID IN RHEUMATOID ARTHRITIS*
}

\author{
BY \\ P. ELLING, H. GRAUDAL, AND V. FABER \\ From the ANF Laboratory, Streptococcal Department, Statens Seruminstitut, Copenhagen, \\ and the Rheumatism Research Unit, Arhus University, Arhus, Denmark
}

Previous papers have dealt with questions concerning granulocyte-reactive antinuclear factors (ANF) occurring in rheumatoid arthritis and some other disorders (Faber, Elling, Norup, Mansa, and Nissen, 1964; Faber and Elling, 1966; Elling, 1967; Elling and Graudal, 1968; Elling, Graudal, and Faber, 1967). In this report data are presented concerning the occurrence and nuclear specificity of ANF in synovial fluids. Barnett, Bienenstock, and Bloch $(1964,1966)$ have reported ANF in nine out of 21 rheumatoid synovial fluids, and MacSween, Dalakos, Jasani, Wilson, Boyle, Buchanan, and Goudie (1967), using rat liver as nuclear source, in 23 per cent.

\section{Material and Methods}

Specimens of synovial fluid and serum from fifty rheumatoid patients were studied.

Twelve males and 31 females suffered from adult definite or classic rheumatoid arthritis according to ARA-criteria (1959). Their mean age was $51 \cdot 4$ years (range 16-70). The mean duration of disease was 8.8 years (range 3 months-29 years). In five patients the duration was less than 1 year; in four, 1-2 years; in five, 2-5 years; in 29, more than 5 years. Two patients were in stage I; nine in stage II; 30 in stage III; two in stage IV. The Waaler-Rose test was positive in 34 and in one further patient the latex-fixation test was positive, so that eight patients were sero-negative.

Three females suffered from psoriatic arthritis; their ages were 42,46 , and 47 years; disease stage III, III, and I; duration of disease 32 years, 18 months, and 4 months.

Three females and one male suffered from juvenile

\footnotetext{
*Supported by a grant from the Daell Foundation.
}

poly-arthritis in stage II; their ages were $30,15,11$, and 14 years; duration of disease $24,2,1 \frac{2}{3}$, and 5 years.

All the patients were treated as one group, but any special characteristics of the small subgroups will be stated.

The synovial fluids were drawn from the knee joints, with two exceptions: one shoulder and one ankle. The local arthritis activity of the aspirated joint was estimated as slight $(+)$ if only a slight tenderness or a slight swelling was present; and as pronounced $(++)$ if both were present, or if the degree of tenderness or swelling was pronounced.

The following data were also considered: erythrocyte sedimentation rate; amount of synovial fluid aspirated; total cell counts and differential cell counts in the synovial fluids.

Two-layer and three-layer immunofluorescent techniques were used for the detection of ANF with human blood smears, thyroid sections, and gastric mucosa, besides rat-liver sections as nuclear source (as described by Elling, 1967b).

Rheumatoid factors were determined by the sheep-cell agglutination test, using a slight modification of Waaler's method (Bichel, Holten, Jensen, and Christensen, 1957) and by the FII latex test (Hyland reagent).

In a few cases, unfixed smears of sedimented synovial fluid cells were incubated with fluorescein-isothiocyanatelabelled rabbit anti-human gammaglobulin or FITClabelled rabbit anti-human beta ${ }_{1 C}$ globulin (obtained unconjugated from Red Cross Central Lab., Amsterdam) for 30 minutes; after washing, they were mounted in buffered glycerin and observed by fluorescence microscopy.

\section{Results}

ANF occurred in the synovial fluids of 31 and in the serum of 32 of the fifty patients studied (Table I),

TABLE I

INCIDENCE OF ANF IN SYNOVIAL FLUID AND SERUM FROM FIFTY PATIENTS WITH DEFINITE RHEUMATOID ARTHRITIS

\begin{tabular}{|c|c|c|c|c|c|c|c|}
\hline \multirow{2}{*}{$\begin{array}{c}\text { Material } \\
\text { Tested }\end{array}$} & \multirow{2}{*}{$\begin{array}{l}\text { No. of } \\
\text { Cases }\end{array}$} & \multicolumn{5}{|c|}{$\begin{array}{l}\text { Number of Fluids and Sera } \\
\text { containing ANF Reactive with Nuclei of: }\end{array}$} & \multirow{2}{*}{$\begin{array}{l}\text { Total } \\
\text { ANF-Positive }\end{array}$} \\
\hline & & Granulocytes & Lymphocytes & Thyroid Tissue & Gastric Mucosa & Rat Liver & \\
\hline Synovial Fluids & 50 & 30 & 18 & 17 & 16 & 15 & 31 \\
\hline Serum & 50 & 29 & 17 & 22 & 14 & 19 & 32 \\
\hline
\end{tabular}


but with marked differences depending on the tissue used as nuclear antigen. Whereas granulocytereactive ANF occurred in about 60 per cent. of sera and synovial fluids, ANF-reactive with lymphocytes, thyroid, gastric mucosa, and rat-liver nuclei were found in $34,44,28$, and 38 per cent. respectively of the sera and in $36,34,32$, and 30 per cent respectively of the synovial fluids. Granulocytespecific ANF (Fig. 1) occurred solely in twelve? synovial fluids and in nine sera (Table IIA, below, and IIB, opposite).

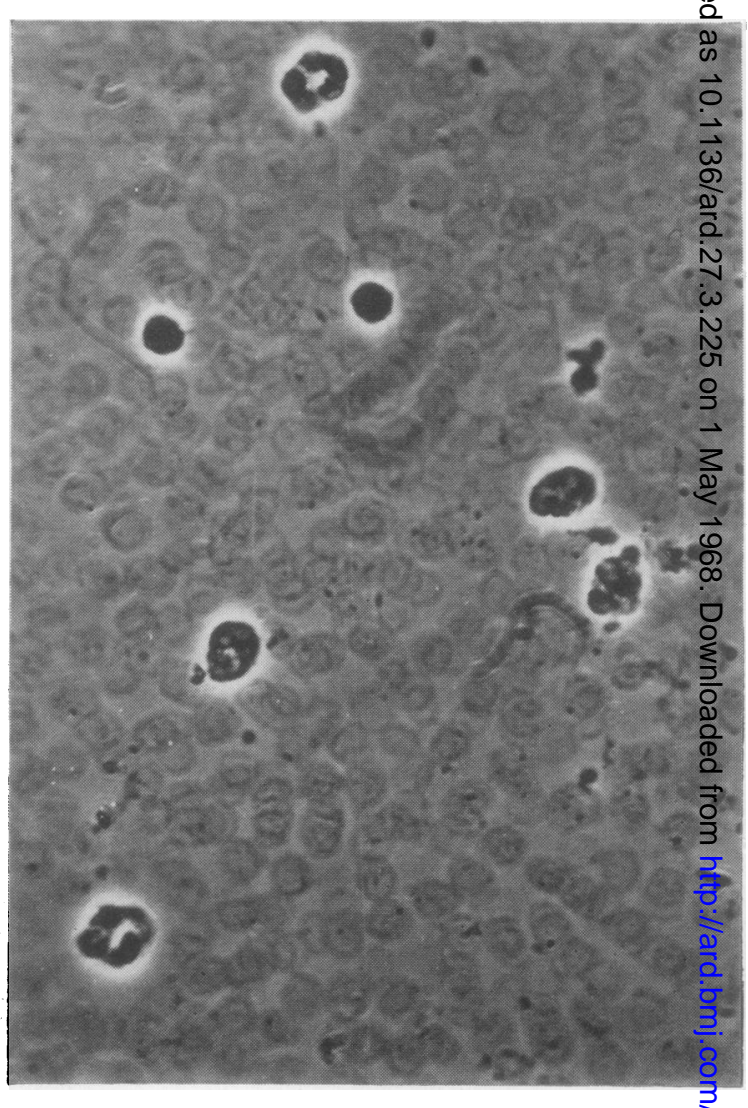

Fig. 1b.-Phase-contrast picture of the same field as that shown in Fig. 1a. $\times 260$.

TABLE IIA

NUCLEAR SPECIFICITY OF ANF IN SYNOVIAL FLUID

\begin{tabular}{|c|c|c|c|c|c|}
\hline \multirow{2}{*}{$\begin{array}{l}\text { Number } \\
\text { of Cases }\end{array}$} & \multicolumn{5}{|c|}{ Reactivity of Synovial Fluids with Nuclei of: } \\
\hline & Granulocytes & Lymphocytes & Thyroid Tissue & Gastric Mucosa & Rat Liver \\
\hline $\begin{array}{r}12 \\
12 \\
1 \\
1 \\
1 \\
1 \\
1 \\
1 \\
1\end{array}$ & $\begin{array}{l}+ \\
+ \\
+ \\
+ \\
+ \\
+ \\
+ \\
+ \\
0\end{array}$ & $\begin{array}{l}+ \\
0 \\
+ \\
+ \\
+ \\
+ \\
+ \\
+ \\
0\end{array}$ & $\begin{array}{l}+ \\
0 \\
0 \\
+ \\
+ \\
0 \\
+ \\
+ \\
+\end{array}$ & $\begin{array}{l}+ \\
\mathbf{0} \\
+ \\
\mathbf{0} \\
+ \\
+ \\
+ \\
\mathbf{0} \\
\mathbf{0}\end{array}$ & $\begin{array}{l}+ \\
\mathbf{0} \\
+ \\
\mathbf{0} \\
\mathbf{0} \\
+ \\
\mathbf{0} \\
+ \\
\mathbf{0}\end{array}$ \\
\hline $\begin{array}{c}31 \\
\text { Percentage }\end{array}$ & $\begin{array}{l}30 \\
96\end{array}$ & $\begin{array}{l}18 \\
58\end{array}$ & $\begin{array}{l}17 \\
54\end{array}$ & $\begin{array}{l}16 \\
51\end{array}$ & $\begin{array}{l}15 \\
50\end{array}$ \\
\hline
\end{tabular}


TABLE IIB

NUCLEAR SPECIFICITY OF ANF IN SERUM

\begin{tabular}{|c|c|c|c|c|c|}
\hline \multirow{2}{*}{$\begin{array}{l}\text { Number } \\
\text { of Cases }\end{array}$} & \multicolumn{5}{|c|}{ Reactivity of Sera with Nuclei of: } \\
\hline & Granulocytes & Lymphocytes & Thyroid Tissue & Gastric Mucosa & Rat Liver \\
\hline $\begin{array}{r}12 \\
9 \\
1 \\
1 \\
1 \\
2 \\
2 \\
1 \\
1 \\
1 \\
1\end{array}$ & $\begin{array}{l}+ \\
+ \\
+ \\
+ \\
+ \\
+ \\
+ \\
+ \\
+ \\
\mathbf{0} \\
\mathbf{0} \\
\mathbf{0}\end{array}$ & $\begin{array}{c}+ \\
0 \\
0 \\
0 \\
0 \\
+ \\
+ \\
0 \\
0 \\
+ \\
0\end{array}$ & $\begin{array}{l}+ \\
\mathbf{0} \\
+ \\
+ \\
+ \\
+ \\
+ \\
+ \\
+ \\
+ \\
+ \\
+\end{array}$ & $\begin{array}{l}+ \\
0 \\
+ \\
0 \\
0 \\
0 \\
0 \\
0 \\
0 \\
+ \\
0\end{array}$ & $\begin{array}{l}+ \\
0 \\
+ \\
+ \\
0 \\
0 \\
+ \\
+ \\
0 \\
+ \\
+\end{array}$ \\
\hline $\begin{array}{c}32 \\
\text { Percentage }\end{array}$ & $\begin{array}{l}29 \\
90\end{array}$ & $\begin{array}{l}17 \\
53\end{array}$ & $\begin{array}{l}22 \\
66\end{array}$ & $\begin{array}{l}14 \\
43\end{array}$ & $\begin{array}{l}19 \\
59\end{array}$ \\
\hline
\end{tabular}

Table IIA further shows that, while 96 per cent. of the total ANF-positive synovial fluids reacted with the nuclei of granulocytes, a significantly $(P<0.01)$ smaller number of synovial fluids contained ANF which reacted with other human and animal tissue nuclei. Only one ANF-positive synovial fluid containing thyroid-reactive ANF contained no granulocyte-reactive ANF. In sera thyroid-specific and rat-liver-specific ANF were found in two cases.

Granulocyte-reactive ANF (Fig. 2) were demonstrated in both sera and synovial fluids in 25 cases, in sera only in four cases, and in synovial fluids only in five cases. In sixteen cases no granulocytereactive ANF were found in either serum or synovial fluid (Table III, overleaf).

Granulocyte-ANF in twenty sera and 21 synovial fluids were found in all of the three human immunoglobulin classes and were in most cases mixtures of two or three immuno-globulins. However, ANF with IgG specificity were found in all ANF-positive synovial fluids tested; in five cases, ANF were found in the IgG immuno-globulin class only.

Cell counts were not performed on four synovial fluids because of clotting; granulocyte counts were thus available for 46 synovial fluids. In granulocyteANF-positive synovial fluids, the number of granulocytes varied from 0 to 27,000 cells per $\mu$ l. (Fig. 3, overleaf). In nineteen of these fluids less than 10,000 and in eight more than 10,000 granulocytes

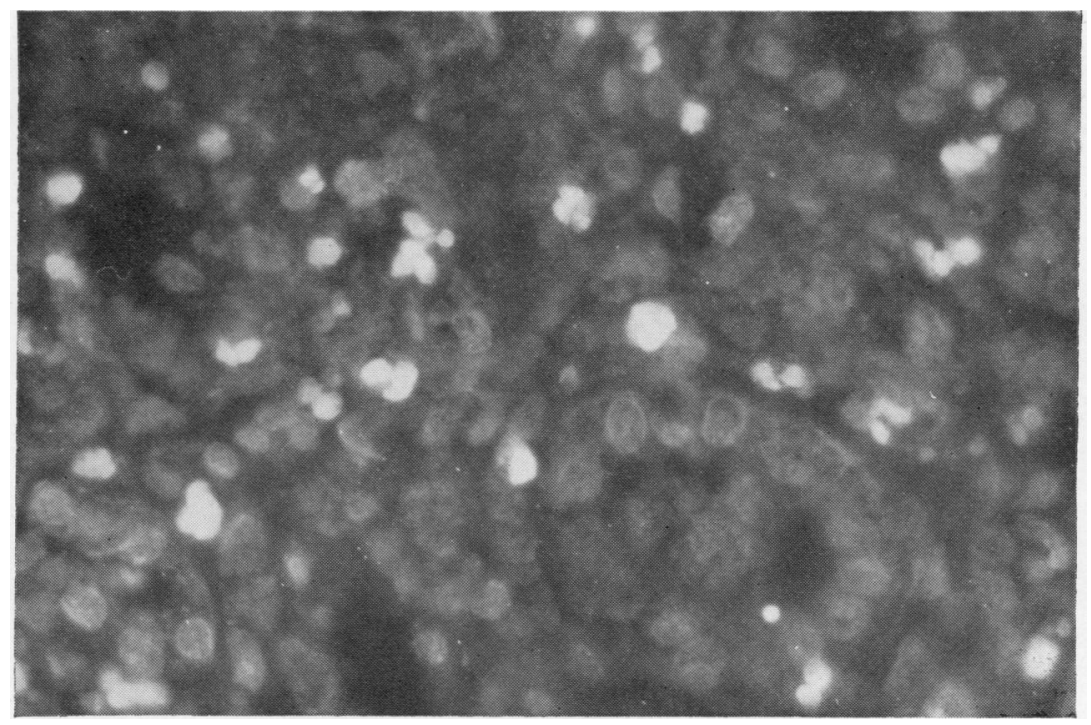

Fig. 2.-Cryostat section of human kidney tissue incubated with serum containing granulocytereactive ANF and then FITC-labelled rabbit anti-human-gammaglobulin, showing strong fluorescence of nuclei of infiltrating polymorphs together with weak staining of nuclei of tubular epithelial cells. $\times 260$. 
TABLE III

COMPARISON OF INCIDENCE OF GRANULOCYTE-REACTIVE ANF IN SERA AND SYNOVIAL FLUIDS FROM FIFTY PATIENTS WITH RHEUMATOID ARTHRITIS

\begin{tabular}{|c|c|c|c|c|}
\hline \multirow{2}{*}{\multicolumn{3}{|c|}{ Granulocyte ANF }} & \multicolumn{2}{|c|}{ Synovial Fluid } \\
\hline & & & \multirow{2}{*}{$\frac{\text { Positive }}{25}$} & \multirow{2}{*}{$\frac{\text { Negative }}{4}$} \\
\hline \multirow{2}{*}{ Serum } & Positive & $\ldots$ & & \\
\hline & Negative & $\ldots$ & 5 & 16 \\
\hline
\end{tabular}

per $\mu 1$. were found. In contrast, in seventeen out of nineteen granulocyte-ANF-negative synovial fluids, the number of granulocytes varied from 11,000 to 80,000 cells per $\mu 1$. and in only two ANF-negative synovial fluids were the counts lower than 10,000 . One of the latter fluids originated from the knee joint of a 62-year-old man with a fresh attack of sero-negative polyarthritis. The other was derived from the ankle joint of a 14-year-old boy with seronegative polyarthritis; he had a family history of ankylosing spondylitis, though this disease could not be verified in his case.

While the mean count of granulocytes was approximately three times fewer in ANF-positive synovial fluids than in synovial fluids showing no ANF reaction, Fig. 4 shows that the number of mononuclear cells was uniformly distributed in ANF-positive and ANF-negative synovial fluids. The mean counts of mononuclear cells in ANFpositive synovial fluids were 3,002 cells per $\mu 1$. and in ANF-negative synovial fluids, it was 3,455 cells per $\mu 1$., a difference which is not statistically signifi- cant. In five ANF-positive synovial fluids, more than 50 per cent. of the cells were found to be mononuclear, a ratio which was never found in any ANF-negative synovial fluids.

A further comparison of the thirty patients with granulocyte-ANF-positive synovial fluids and the twenty patients with granulocyte-ANF-negative synovial fluids is given in Table IV (opposite). The two groups were fairly similar as regards systemic and local arthritis activity. The FII latex test was positive in 77 per cent. of granulocyte-ANF-positive and in 47 per cent. of granulocyte-ANF-negative synovial fluids; the Waaler-Rose test in 71 and 52 per cent. respectively. Out of eight adult rheumatoid patients who were negative for rheumatoid factor, four had granulocyte ANF in synovial fluid and serum, and one in serum only. Low cell counts were more frequently associated with the presence of both ANF and rheumatoid factors, while rheumatoid factors without ANF were mostly found in synovial fluids with high cell counts.

Granulocyte-reactive ANF occurred in both early and late cases. In two patients with adult rheumatoid arthritis of less than 1 year's duration, granulocyte-reactive ANF were found in serum and synovial fluid, in two patients in serum only, and in one patient in neither. In four adult rheumatoid patients with disease of 1-2 years' duration, granulocyte ANF were found both in serum and synovial fluid; in one patient no granulocyte ANF were found. In two psoriatic and two juvenile rheuma-

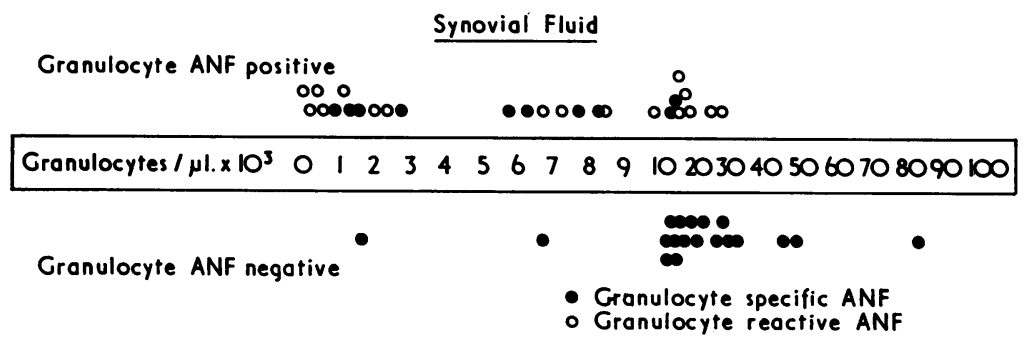

Fig.3.-Comparison between number of granulocytes and occurrence of granulocyte-specific and granulocyte-reactive ANF in 46 synovial fluids

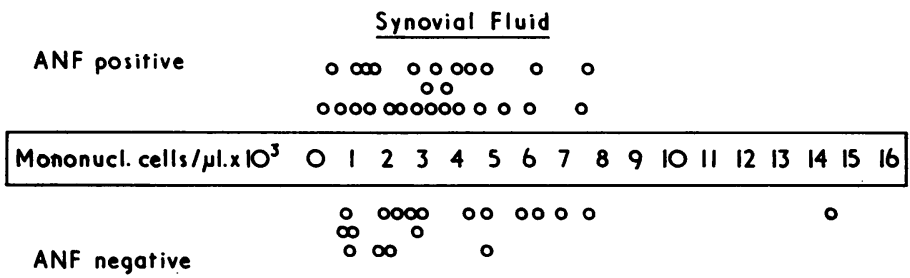

Fig. 4.-Comparison between number of mononuclear cells and occurrence of granulocyte ANF in 46 synovial fluids. 
TABLE IV

RANGE AND MEAN OF CELLS, ASPIRATED SYNOVIAL FLUID VOLUME, RHEUMATOID FACTORS, AND LOCAL ARTHRITIS ACTIVITY IN ANF-POSITIVE AND NEGATIVE SYNOVIAL FLUIDS ERYTHROCYTE SEDIMENTATION RATE MEASURED IN CORRESPONDING SERA

\begin{tabular}{|c|c|c|c|c|c|c|}
\hline \multirow{3}{*}{\multicolumn{2}{|c|}{ Test }} & & \multicolumn{4}{|c|}{ Granulocyte ANF } \\
\hline & & & \multicolumn{2}{|c|}{ Positive } & \multicolumn{2}{|c|}{ Negative } \\
\hline & & & Mean & Range & Mean & Range \\
\hline $\begin{array}{l}\text { White Cells per } \mu \mathrm{l} . \\
\text { Per cent. Granulocytes } \\
\text { Granulocytes per } \mu \mathrm{l} \text {. } \\
\text { Mononuclear Cells per } \mu \mathrm{l} \text {. } \\
\text { Synovial Fluid (ml.) } . . \\
\text { Local Arthritis Activity } \\
\quad(++/+ \text { number of joints } \\
\text { Erythrocyte Sedimentation } \\
\text { (mm./hr) } \ldots \\
\text { FII Latex Test } \geqslant 1: 20 \\
\text { SCAT Test } \geqslant 1: 80 \ldots\end{array}$ & $\begin{array}{l}\cdots \\
\cdots \\
\cdots \\
\cdots \\
\text { s) } \\
\text { Rate } \\
\cdots \\
\cdots \\
\cdots\end{array}$ & $\begin{array}{l}\cdots \\
\cdots \\
\cdots \\
\cdots \\
\cdots \\
\cdots \\
\cdots \\
\cdots\end{array}$ & $\begin{array}{c}12,248 \\
63 \cdot 5 \\
8,702 \\
3,002 \\
16 \\
20 / 10 \\
56 \\
17 / 22 \text { (77 per cent.) } \\
16 / 21 \text { (71 per cent.) }\end{array}$ & $\begin{array}{c}1,500-34,700 \\
0-86 \\
0-27,066 \\
225-7,854 \\
0 \cdot 5-70 \\
\\
\\
10-116\end{array}$ & $\begin{array}{c}27,982 \\
82 \\
24,044 \\
3,455 \\
19 \\
12 / 8 \\
56 \\
9 / 19 \text { (47 per cent.) } \\
9 / 17 \text { (52 per cent.) }\end{array}$ & $\begin{array}{c}3,600-96,000 \\
45-97 \\
1,620-81,600 \\
800-14,440 \\
2-50 \\
\\
10-110\end{array}$ \\
\hline
\end{tabular}

toid patients with a disease of less than 2 years' duration, no granulocyte ANF were found. Granulocyte-reactive ANF may be less typical of psoriatic and juvenile rheumatoid arthritis, though they can occur in these variants. The patients with psoriatic and juvenile arthritis were sero-negative, except that one male with juvenile arthritis showed a weaklypositive latex test. In synovial fluids, granulocytereactive ANF were found in only one psoriatic

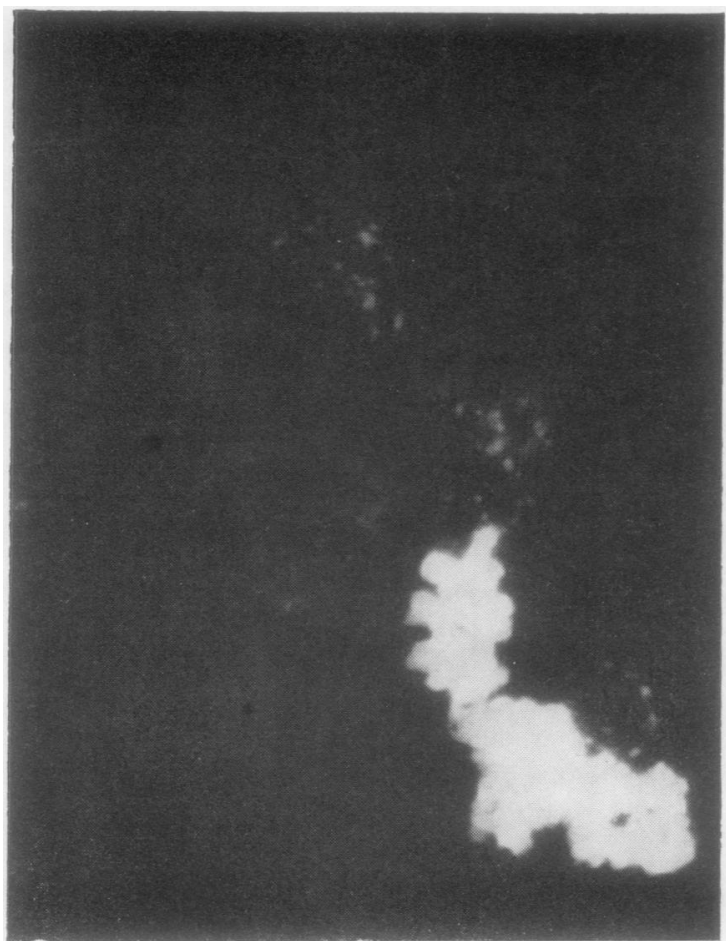

Fig. 5a.-Smears of cells from ANF-positive synovial fluids observed by UV-microscopy after incubation with FITC-labelled rabbit antihuman-gammaglobulin. Fluorescence of isolated nuclei and nuclear fragments, but no nuclear fluorescence of intact cells. $\times 260$. patient, while two psoriatic and four juvenile arthritis patients had no granulocyte ANF in either synovial fluid or serum.

In the experiments shown in Figs 5 and 6, smears of synovial fluid cells were stained for the presence and localization of gamma-globulin and complement. The synovial fluids used were "old", containing disintegrated and disintegrating cells. Compact masses, besides structures that morphologically

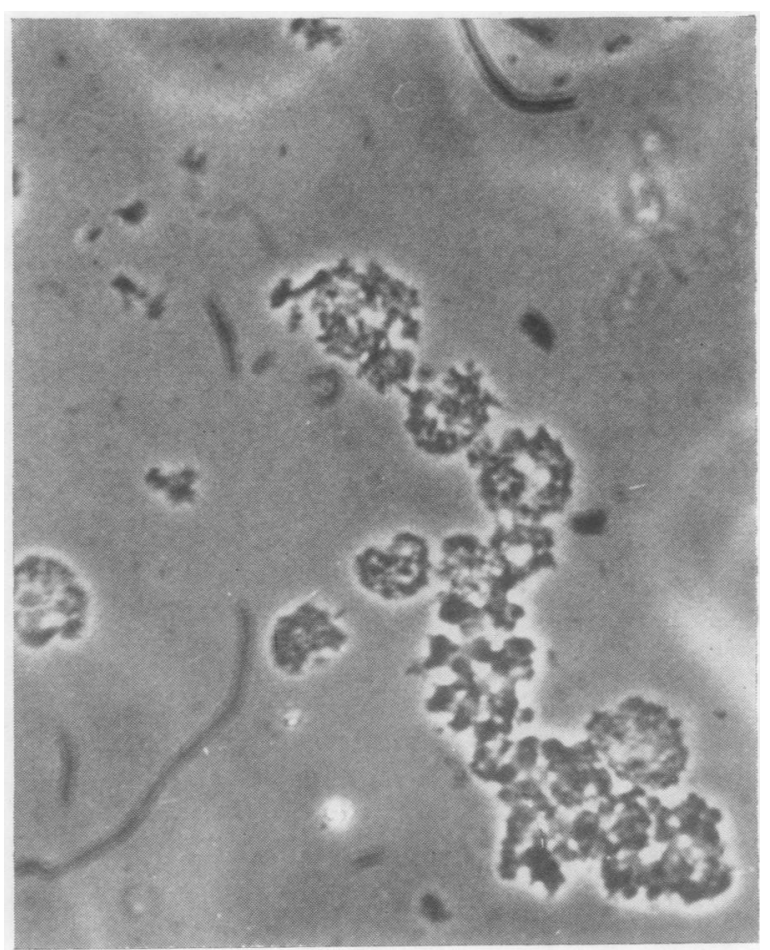

Fig. 5b.-Phase-contrast picture of the same field as that shown in Fig. $5 a . \times 260$. 


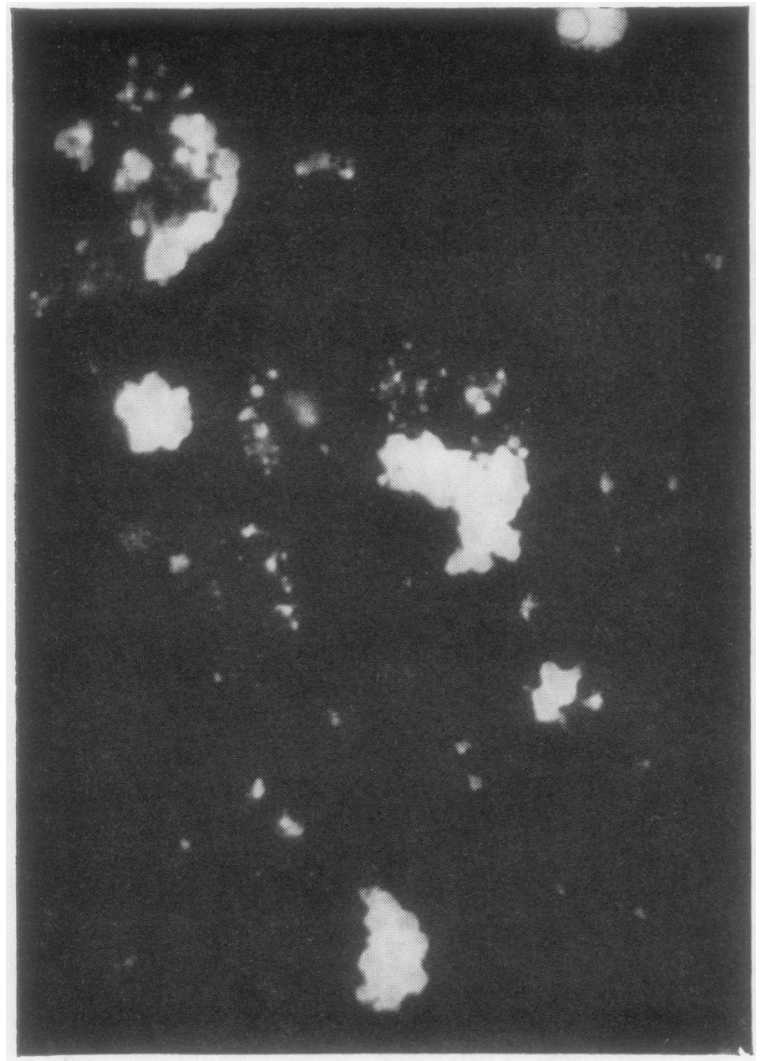

Fig. 6a.-Smears of cells from ANF-positive synovial fluids observed by UV-microscopy after pre-treatment of the slides with FITClabelled rabbit anti-human-betalc-globulin $\left(\mathrm{C}_{\mathbf{s}}\right)$. Fluorescence localized to isolated nuclei and nuclear fragments, but no fluorescence of nuclei of intact cells. $\times 260$.

were isolated nuclei or nuclear fragments, showed intense fluorescence-probably owing to the binding of antinuclear factors and complement to nucleoproteins of disintegrated cells. Nuclear fluorescence of intact granulocytes or mononuclear cells was not observed, except in a few cases. Small fluorescent dots were seen on the surface of or in the cytoplasm of some, apparently intact, leucocytes.

Sediments of cells from synovial fluids centrifuged immediately after the aspiration show-after washing - a considerably lesser fluorescence when incubated with FITC-labelled anti-human gammaglobulin and anti-beta ${ }_{1 c}$ globulin. In such "fresh" sediments only approximately 1 per cent. of the cells shows nuclear fluorescence. Thus, although the binding of gammaglobulin to nuclear material appears to occur in vivo, this binding is much enhanced in vitro.

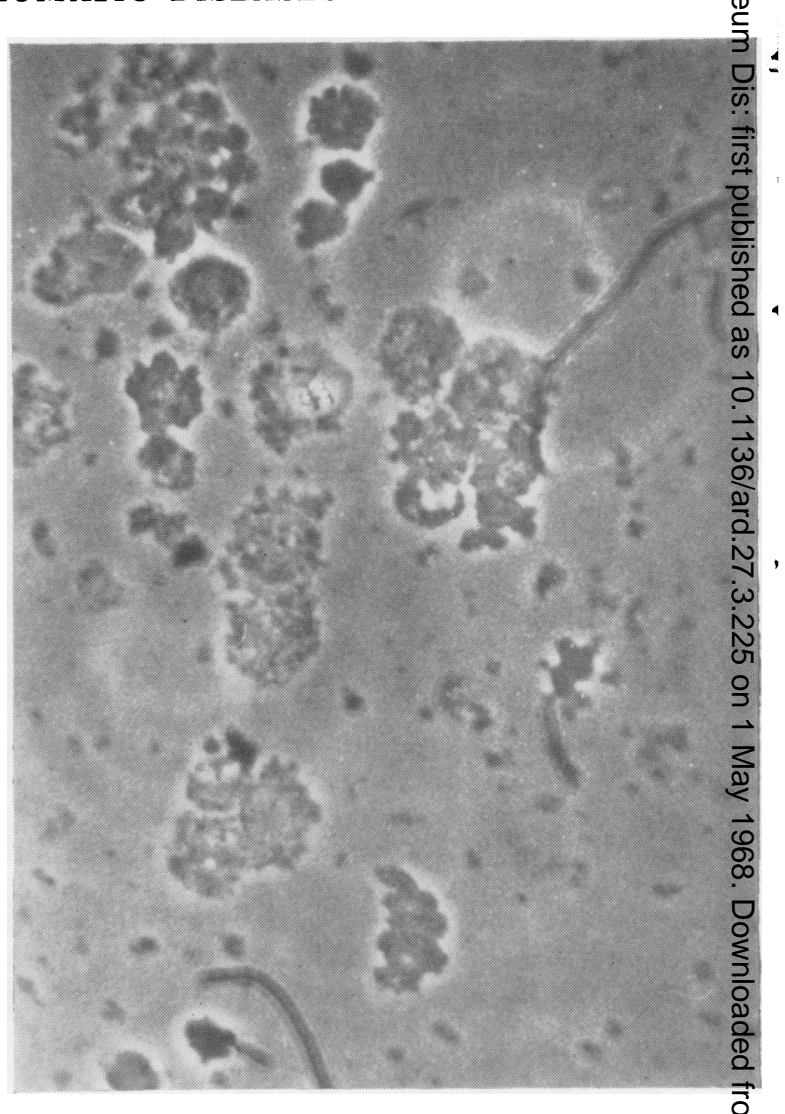

Fig. 6b.-Phase-contrast picture of the same field as that shown in Fig. $6 a . \times 260$.

\section{Discussion}

Comparative investigations of the nuclear reactivity of sera from patients with adult rheumatoid 음 arthritis have revealed that, in rheumatoid arthritis, $D$ ANF exhibit a limited nuclear reactivity directed mainly against a nuclear antigen in the polymorpho- $N$ nuclear granulocytes (Elling, 1967a; Elling and others, 1967). The present findings of granulocyte-reactive 0 ANF in the serum of about 60 per cent. of adult $\tilde{\omega}$ rheumatoid patients and a lower incidence of ANFO reactive with other human and animal nuclei agreeco with these results. A similar incidence and disso- $\bar{\varnothing}$ ciated nuclear reactivity have been found in synovial $\stackrel{\mathcal{\infty}}{+}$ fluids. The high incidence of granulocyte-reactive $\underset{T}{T}$ ANF and the lower incidence of ANF reactive with $\frac{\vec{P}}{\bar{D}}$ other nuclei demonstrated in the present report agree $\stackrel{\mathbb{\Phi}}{\stackrel{\circ}{\circ}}$ fairly well with previous reports. Barnett and $\stackrel{\varnothing}{\varrho}$ others (1964), using leucocytes as antigen, found 
ANF in 42 per cent. of 22 synovial fluids investigated, while MacSween and others (1967), using rat livers only as nuclear source, were able to demonstrate ANF in 23 per cent. of 110 synovial fluids from patients with rheumatoid arthritis.

The high incidence of granulocyte-reactive ANF found in sera and synovial fluids suggests that this antibody is just as typical a feature of rheumatoid arthritis as is rheumatoid factor, with the possible exception of juvenile rheumatoid arthritis. The absence of granulocyte-reactive ANF in all of the four patients with juvenile rheumatoid arthritis does not, however, allow general conclusions to be drawn. According to Barnett, Leddy, Condemi, and Vaughan (1965), ANF in children seem to occur at a later stage of the disease. In one of our patients with juvenile rheumatoid arthritis, an ANF reaction with thyroid nuclei only was found in both serum and synovial fluid. This patient was 30 years old and had had recurrent attacks of polyarthritis since the age of 6 years.

Our demonstration of granulocyte-specific ANF in twelve synovial fluids and in nine sera showed that a high percentage of ANF in rheumatoid arthritis does not show the organ non-specificity that is considered to be a fundamental characteristic of ANF in systemic lupus erythematosus.

An unexpected correlation occurred between the finding of granulocyte-reactive ANF in synovial fluid and low fluid counts of granulocytes, whereas no similar correlation was found as regards the number of mononuclear cells. At least three mechanisms may be involved in this phenomenon, either separately or working together:

(1) Disintegration of granulocytes may release nuclear proteins able to bind $A N F$.- Such nuclear materials have previously been demonstrated free in synovial fluids (Zucker-Franklin, 1966) and, since synovial fluids with high cell counts probably contain the highest concentration of free nucleo-proteins, the ANF reaction should tend to be negative in synovial fluids with high cell counts. Our demonstration of isolated nuclear fragments coated with gammaglobulin in synovial fluids suggests that ANF may be bound also in vivo. This implies that the incidence of ANF demonstrated in the synovial fluids is a minimum one.

(2) The number of granulocytes must also depend on the rate of disintegration.- There is some evidence that immunocomplexes may cause granulocytolysis when phagocytosed (Hollander, McCarty, Astorga, and Castro-Murillo, 1965; Astorga and Bollet, 1965). It is conceivable that ANF and nucleoprotein, together with the rheumatoid factor, may form soluble or particulate immunocomplexes and ANF may participate in the rheumatoid inclusion bodies (Barnett and others, 1964, 1966). Actually a lower granulocyte count was found in synovial fluids containing granulocyte-reactive ANF and the rheumatoid factor as compared with synovial fluids, which were ANF-negative, although containing rheumatoid factors. A direct cytopathogenic effect of ANF is less likely, since many previous investigations have shown that ANF do not react with the intact cells. This also agrees with the present finding of the reactivity of ANF with cells in synovial fluids.

(3) The number of granulocytes in the synovial fuids must depend upon the intensity of the exudation.However, according to Ropes and Bauer (1953), there is, in rheumatoid arthritis, little evidence of any cytological variation with severity, when cell counts are compared with estimates of the severity of the disease as a whole. In the present series of cases the severity of the disease was very similar in the ANF-positive and the ANFnegative groups, judging from the erythrocyte sedimentation rate, synovial fluid volume, and estimated local arthritis activity. Thus a difference in activity can hardly mean much to the difference in granulocyte counts in ANF-positive and ANF-negative synovial fluids, though if estimated individual joint activity is compared with granulocyte counts, it appears that, at least in some of the patients with granulocyte counts less than 5,000 cells per $\mu 1$., these low counts may be related to a slight arthritis activity.

The nuclear specificity of synovial ANF suggests the existence of a nuclear material-probably a DNA-histone complex - in the polymorphonuclear granulocytes as the immunizing agent, whereas the formation of antinuclear factors with such a limited nuclear specificity by nuclear material of viral or bacterial origin seems unlikely. The finding of granulocyte-specific ANF in synovial fluid only in some cases suggests that the antigen is derived from polymorphonuclear granulocytes involved in the arthritic lesion. Further work is needed to determine whether any long-lasting infection with a continuous suppuration results in the formation of granulocyte-specific ANF, or whether the production of such factors presupposes a qualitative change of the antigen or a certain genetic predisposition.

\section{Summary}

Synovial fluids and sera from fifty patients with definite rheumatoid arthritis were investigated for the presence and nuclear specificity of antinuclear factors, using the fluorescent antibody technique with several human and animal tissues as antigen.

The overall incidence of antinuclear factors in sera was 64 per cent. and in synovial fluids 62 per cent., but this high incidence was mainly caused by a high prevalence of antinuclear factors reactive with the nuclei of polymorphonuclear granulocytes. Thus, while 90 per cent. of the ANF-positive sera and 96 per cent. of the ANF-positive synovial fluids reacted with the nuclei of granulocytes, a statistically significant smaller number $(P<0.01)$ of sera and synovial fluids reacted with other nuclei tested; 
these included some of the most common antigens used for the detection of antinuclear factors. In accordance with these findings, granulocyte-specific antinuclear factors were found in twelve synovial fluids and in nine sera.

In 25 cases, granulocyte-reactive ANF were found in sera and synovial fluids, while in sixteen cases the ANF reaction was negative in sera and synovial fluids. In five cases, granulocyte-reactive ANF were found in synovial fluids only, and in four cases in sera only. An unexpected correlation occurred between the finding of granulocyte-reactive ANF in $\frac{0}{\omega}$ synovial fluids and low cell counts. The mean count of granulocytes was approximately three times fewer in granulocyte-ANF-positive synovial fluids, $\overline{0}$ while the mean count of mononuclear cells showed no significant difference between ANF-positive and $\overline{\bar{m}}$. ANF-negative synovial fluids. The mechanism $\widetilde{\odot}_{\odot}$ which may be concerned in this correlation is briefly discussed.

\section{REFERENCES}

American Rheumatism Association (1959). Arthr. and Rheum., 2, 16 (1958 Revision of diagnostic criteria for rheumatoid arthritis).

Astorga, G., and Bollet, A. J. (1965). Ibid., 8, 511 (Diagnostic specificity and possible pathogenetic significance of inclusions in synovial leucocytes).

Barnett, E. V., Bienenstock, J., and Bloch, K. J. (1964). Ibid., 7, 726 (Antinuclear factors in synovial fluids: Possible participants in the rheumatoid inclusion body).

- - - - (1966). J. Amer. med. Ass., 198, 143 (Antinuclear factors in synovia. Possible participants in the rheumatoid inclusion body).

—, Leddy, J. P., Condemi, J. J., and Vaughan, J. H. (1965). Ann. N.Y. Acad. Sci., 124, 896 (Antinuclear factors in rheumatoid arthritis).

Bichel, J., Holten, C., Jensen, K. B., and Christensen, A. S. (1957). Acta med. scand., 158, 351 (The Waaler-Rose test with special reference to cancer).

Elling, P. (1967a). Acta rheum. scand., 13, 101 (On the incidence of antinuclear factors in rheumatoid arthritis).

- (1967b). Acta path. microbiol. scand., 69, 384 (Reaction of antinuclear factors with polymorphonuclear granulocytes. 2. On the inaccessibility of intact leucocytes to granulocytespecific ANF of high molecular weight).

- and Graudal, H. (1968). Acta med. scand., 183, 25 (Ig-G, Ig-A, and Ig-M granulocyte reactive ANF in rheumatoid arthritis).

$\longrightarrow,-$, and Faber, V. (1967). Ibid., 182, 707 (Organ-specific and organ-non-specific autoantibodies in rheumatoid arthritis).

Faber, V., and Elling, P. (1966). Ibid., 179, 257 (Leucocyte-specific anti-nuclear factors in patients with Felty's syndrome, rheumatoid arthritis, systemic lupus erythematosus and other diseases).

- - - Norup, G., Mansa, B., and Nissen, N. I. (1964). Lancet, 2, 344 (An antinuclear factor specific for leucocytes).

Hollander, J. L., McCarty, D. J., Astorga, G., and Castro-Murillo, E. (1965). Ann. intern. Med., 62, 271 (The "R.A. cell" and a working hypothesis).

MacSween, R. N. M., Dalakos, T. K., Jasani, M. K., Wilson, M. E., Boyle, J. A., Buchanan, W. W., and Goudie, R. B. (1967). Lancet, 1, 312 (Anti-nuclear factors in synovial fluids).

Ropes, M. W., and Bauer, W. (1953). "Synovial Fluid Changes in Joint Disease". Harvard University Press, Cambridge, Mass.

Zucker-Franklin, D. (1966). Arthur. and Rheum., 9, 24 (The phagosomes in rheumatoid synovial fluid leukocytes: a light, fluorescence, and electron microscope study).

Facteurs anti-nucléaires spécifiques du granulocyte dans le sérum et le liquide synovial des malades atteints de polyarthrite rhumatoide

RÉSUMÉ

On a recherché dans le liquide synovial et le sérum de 50 malades atteints de polyarthrite rhumatoïde "définie" l'existence et la spécificité nucléaire des facteurs antinucléaires, en utilisant le procédé des anticorps fluorescents avec, pour antigène, plusieurs tissus d'origine humaine et animale.
Factores antinucleares específicos del granulocito en $\bar{T}$ suero y el líquido sinovial de enfermos con poliartritis reumatoide

Sumario

Se investigaron en el líquido sinovial y en el suero de 50 enfermos con poliartritis reumatoide "definida" 1 Q existencia y la especificidad nuclear de factores ant $\mathrm{B}$ nucleares, empleando el método de anticuerpos fluores centes y utilisando, como antígenos, varios tejidos de origen animal y humano. 
L'incidence totale des facteurs anti-nucléaires dans les sérums était de 64 pour cent et dans le liquide synovial de 62 pour cent, mais cette incidence élevée était due principalement à la forte prédominance des facteurs antinucléaires réagissant avec les noyaux des granulocytes polymorphonucléaires. Ainsi, tandis que 90 pour cent des sérums et 96 pour cent des liquides synoviaux contenant des facteurs anti-nucléaires réagissaient avec les noyaux des granulocytes, un nombre plus petit mais statistiquement significatif $(p<0,01)$ des sérums et des liquides synoviaux réagissait avec d'autres noyaux examinés; il y avait parmi eux quelques uns des antigènes les plus communs utilisés pour déceler les facteurs antinucléaires. En accord avec ces résultats on a trouvé dans 12 liquides synoviaux et neuf sérums des facteurs anti-nucléaires spécifiques du granulocyte.

Dans 25 cas on a trouvé des facteurs anti-nucléaires réagissant avec le granulocyte dans les sérums et les liquides synoviaux tandis que dans 16 cas on n'en trouva pas. Dans 5 cas on a trouvé des facteurs anti-nucléaires réagissant avec le granulocyte dans le liquide synovial seulement et dans 4 cas dans le sérum seulement. Une corrélation inattendue est apparue entre les résultats de la recherche du facteur anti-nucléaire réagissant avec le granulocyte dans les liquides synoviaux et les chiffres bas de numération cellulaire. Le chiffre moyen des granulocytes était approximativement trois fois plus bas dans les liquides synoviaux contenant des facteurs anti-nucléaires réagissant avec le granulocyte, tandis que le chiffre moyen descellules mononucléairesn'accusait pas de différences significatives entre les liquides synoviaux contenant des facteurs anti-nucléaires et ceux qui n'en contenaient pas. On discute brièvement le mécanisme qui pourrait intervenir dans cette corrélation.
$\mathrm{La}$ incidencia total de factores antinucleares fué de un 64 por ciento en los sueros y de un 62 por ciento en los líquidos sinoviales, pero esta alta incidencia se debió principalmente a un fuerte predominio de factores antinucleares reaccionando con los nucleos de los granulocitos polimorfonucleares. Asi, mientras que un 90 por ciento de los sueros y un 96 por ciento de los líquidos sinoviales contuvieron factores antinucleares que reaccionaban con los núcleos de los granulocitos, un número menor pero estadisticamente significativo $(\mathrm{p}<$ 0,01 ) de los sueros y de los líquidos sinoviales reaccionaba con otros núcleos examinados; encontraronse entre ellos muchos de los antígenos comunamente empleados para revelar los factores antinucleares. De acuerdo con estos resultados, factores antinucleares específicos del granulocito fueron encontrados en doce líquidos sinoviales y en nueve sueros.

En 25 casos factores antinucleares granulocitarios fueron encontrados en los sueros y en los líquidos sinoviales mientras que en 16 casos estos fueron ausentes en ambos medios. En cinco casos estos se vieron sólo en el líquido sinovial y en cuatro casos sólo en el suero. Una correlación inesperada apareció entre los resultados de la investigación del factor antinuclear granulocitario y las cifras bajas del recuento celular. Las cifras medias de los granulocitos fueren aproximadamente tres veces menores en los líquidos sinoviales conteniendo los factores antinucleares granulocitarios, mientras que las cifras medias de las células mononucleares no acusaron diferencias significativas respecto al contenido en factor antinuclear de los líquidos sinoviales. Se discute brevemente el posible mecanismo de esta correlación. 